\title{
Diare Akibat Infeksi Parasit
}

\author{
Herbowo, Agus Firmansyah
}

Diare sebagai salah satu penyakit yang masih sering terjadi di Indonesia dapat disebabkan oleh berbagai hal. Salah satu penyebab yang sering luput dari perhatian kita adalah diare akibat infeksi parasit. Indonesia sebagai negara berkembang dan negara tropis diperkirakan memiliki angka kejadian infeksi parasit yang cukup tinggi. Tidak semua parasit dapat menyebabkan diare. Pengetahuan mengenai jenis parasit yang dapat menyebabkan diare beserta gejala klinisnya diperlukan dalam tata laksana optimal diare akibat infeksi parasit.

Kata kunci: diare, parasit.

$\mathcal{7}$

nfeksi saluran cerna oleh parasit memiliki morbiditas dan mortalitas yang tinggi di seluruh dunia. ${ }^{1-3}$ Berbagai hal dapat menjadi penyebab tingginya angka prevalensi infeksi parasit diantaranya adalah buruknya sanitasi. ${ }^{3-6}$ Angka prevalensi tertinggi infeksi saluran cerna oleh parasit didapatkan di negara berkembang dengan ekonomi rendah terutama di daerah tropis. ${ }^{5-10}$

\section{Definisi}

Diare didefinisikan sebagai buang air besar lebih dari tiga kali sehari dengan konsistensi lembek atau cair, ${ }^{1}$ namun definisi yang lebih banyak dianut adalah apabila terdapat salah satu atau lebih gejala peningkatan frekuensi defekasi, konsistensi feses dan jumlah feses. ${ }^{2-}$ $4,11,12$

Jenis parasit yang dapat menyebabkan diare adalah protozoa (Giardia lamblia, Cryptosporidium sp., Isospora belli, Sarcocystissp., Entamoeba histolytica, Nonpathogenic Amoeba, Balantidium coli), cacing (Strongyloides stercoralis, Capillaria philippinensis, Trichinella spiralis,

Dr. Herbowo Agung, PPDS IKA FKUI, Jakarta.

\section{Alamat Korespondensi:}

Prof.DR. Agus Firmansyah, Sp.A(K)

Subbagian Gastroenterologi. Bagian Ilmu Kesehatan Anak FKUI-RSCM. Jl. Salemba no. 6, Jakarta 10430.

Telepon: 021-3915665, Fax.: 021-3913982.
Trichostrongylus orientalis, Trematoda, Trichuris trichiura), dan jamur (Candida sp., Aspergillus sp., Zygomycosis sp). 8,10

\section{Patogenesis}

\section{A. Giardia lamblia}

Giardia lamblia merupakan penyebab tersering infeksi protozoa pada saluran cerna manusia dan paling banyak ditemukan di negara-negara berkembang., ${ }^{4,6-}$ 8,10,13-15 Prevalensi giardiasis berkisar 10\% di Amerika Utara, Eropa dan hingga mencapai 20\%-30\% di negara berkembang. ${ }^{7,8,14}$ Prevalensi tinggi ditemukan pada anak usia prasekolah dan pada anak dengan gangguan gizi. ${ }^{8}$ Infeksi Giardia lamblia dapat melalui air, makanan, atau langsung melalui rute fekal-oral. ${ }^{4,6-}$ $8,10,13-18$

Giardia lamblia mempunyai dua bentuk yaitu bentuk trofozoit dan kista. Meskipun trofozoit ditemukan di dalam tinja tetapi trofozoit tidak dapat hidup di luar tubuh manusia. Kista adalah bentuk infeksius G.lamblia yang resisten terhadap berbagai macam gangguan di luar pejamu dan dapat bertahan hidup selama sebulan di air atau di tanah. ${ }^{6,7,9,10,13,14-}$ $16,18,19$

Kista matang yang tertelan oleh pejamu akan mengalami ekskistasi di duodenum yang dicetuskan oleh adanya asam lambung lalu diikuti dengan paparan sekresi kelenjar eksokrin pankreas. Dalam proses 
ekskistasi ini sitoplasma akan membelah dan terbentuk 2 trofozoit. Saat trofozoit lepas dari kista terjadi perlekatan ke dinding epitel usus dan terjadi multiplikasi. G.lamblia hidup di duodenum dan di bagian proksimal yeyunum dan kadang-kadang di saluran dan kandung empedu. Pergerakan flagel yang cepat membuat trofozoit bergerak dari satu tempat ke tempat lain dan dengan batil isapnya melekatkan diri

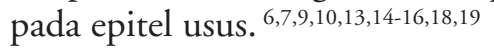

Mekanisme terjadinya diare pada infeksi giardia lamblia belum jelas. Meskipun mukosa yeyunum terlihat normal bila dilihat dengan mikroskop cahaya, namun ternyata didapatkan berbagai bentuk atrofi vilus seperti pemendekan dan distrofi mikrovilus. ${ }^{6-9,14,18,19}$ Aktivitas disakaridase membran mikrovilus berkurang dan terjadi gangguan transport glukosa yang dipengaruhi natrium. ${ }^{14}$ $\mathrm{Hal}$ ini diduga berkaitan dengan sistem imunologik. Pada giardiasis, infiltrasi limfosit timbul sebelum terjadi pemendekan vili dan ternyata terdapat hubungan antara intensitas infiltrasi limfosit dengan beratnya malabsorbsi yang terjadi. ${ }^{10,14}$ Peneliti lain mendapatkan secara in vitro bahwa aktivasi sel $T$ dapat meningkatkan proliferasi sel kripta dan atrofi vili. ${ }^{10,14,18}$ Salah satu studi mendapatkan adanya penurunan asam empedu intralumen pada pasien giardiasis. Giardia akan mengambil asam empedu dan dimasukkan ke dalam sitoplasmanya dan menyebabkan berkurangnya asam empedu intraluminal. Hal ini akan menyebabkan pasien akan mengalami malabsorbsi. ${ }^{14}$

\section{B. Entamoeba histolytica}

E. histolytica ditemukan hampir di seluruh dunia, tetapi prevalensi tertinggi didapatkan di negara-negara berkembang terutama di daerah endemik seperti Durban, Ibadan dan Kampala di Afrika mencapai 50\%.7 Angka mortalitas diperkirakan 75.000 per tahun. Infeksi E. histolytica dapat melalui makanan dan air serta melalui kontak manusia ke manusia. ${ }^{6-10,15-18,20,21}$

Dalam daur hidupnya Entamoeba histolytica mempunyai 3 stadium yaitu bentuk histolitika, minuta dan kista. ${ }^{16}$ Bentuk histolitika dan minuta adalah bentuk trofozoit. Perbedaan antara kedua bentuk trofozoit tersebut adalah bentuk histolitika bersifat patogen dan mempunyai ukuran yang lebih besar dari bentuk minuta. Bentuk histolitika bersifat patogen dan dapat hidup di jaringan hati, paru, usus besar, kulit, otak, dan vagina. Bentuk ini berkembang biak secara belah pasang di jaringan dan dapat merusak jaringan tersebut. Minuta adalah bentuk pokok dan tanpa bentuk minuta daur hidup tak dapat berlangsung. Kista dibentuk di rongga usus besar dan dalam tinja, berinti 1 atau 4 dan tidak patogen, tetapi dapat merupakan bentuk infektif. Dengan adanya dinding kista, bentuk kista dapat bertahan hidup terhadap pengaruh buruk di luar badan manusia. ${ }^{6-8,10,16-18,20}$

Kista matang yang tertelan mencapai lambung masih dalam keadaan utuh karena kista tahan terhadap asam lambung. ${ }^{18}$ Di rongga usus halus terjadi ekskistasi dan keluarlah bentuk-bentuk minuta yang masuk ke dalam rongga usus besar. Bentuk minuta ini berubah menjadi bentuk histolitika yang patogen dan hidup di mukosa usus besar serta menimbulkan gejala. ${ }^{16}$

Bentuk histolitika memasuki mukosa usus besar yang utuh dan mengeluarkan enzim sisstein proteinase yang dapat menghancurkan jaringan yang disebut histolisin. Kemudian bentuk histolitika memasuki submukosa dengan menembus lapisan muskularis mukosa, bersarang di submukosa dan membuat kerusakan yang lebih luas daripada di mukosa usus sehingga terjadi luka yang disebut ulkus amuba. Lesi ini biasanya merupakan ulkus-ulkus kecil yang letaknya tersebar di mukosa usus, bentuk rongga ulkus seperti botol dengan lubang sempit dan dasar yang lebar, dengan tepi yang tidak teratur agak meninggi dan menggaung. Proses yang terjadi terutama nekrosis dengan lisis sel jaringan. Bila terdapat infeksi sekunder, terjadilah proses peradangan yang dapat meluas di submukosa dan melebar ke lateral sepanjang sumbu usus. Kerusakan dapat menjadi luas sekali sehingga ulkus-ulkus saling berhubungan dan terbentuk sinussinus dibawah mukosa. Dengan peristalsis usus, bentuk histolitika dikeluarkan bersama isi ulkus ke rongga usus kemudian menyerang lagi mukosa usus yang sehat atau dikeluarkan bersama tinja. ${ }^{6-10,13,15-18,20,21}$

\section{Trichuris trichiura}

Trichuris trichiura dapat ditemukan baik di negara maju maupun negara berkembang. ${ }^{7-10,16,22}$ Diperkirakan Trichuris trichiura merupakan prevalensi terbesar ketiga infeksi oleh cacing usus dan merupakan penyebab terbanyak diare karena infeksi cacing. ${ }^{22}$ Prevalensi sangat tergantung dari pola sanitasi, higiene perorangan, dan juga status nutrisi seseorang. ${ }^{9}$ Cacing ini terutama ditemukan di daerah panas dan lembab, seperti Indonesia. ${ }^{8-10}$ Di beberapa daerah di Indonesia, prevalensi masih tinggi seperti yang dilaporkan oleh Departemen Kesehatan pada tahun 1990/1991; 53\% 
pada masyarakat Bali, 36,2\% di perkebunan di Sumatra Selatan, 51,6\% pada sejumlah sekolah di Jakarta. ${ }^{16}$

Panjang badan cacing betina kira-kira $5 \mathrm{~cm}$, sedangkan cacing jantan $4 \mathrm{~cm} .{ }^{16,22}$ Cacing dewasa ini hidup di kolon asendens dan sekum dengan bagian anterior yang menyerupai cambuk masuk ke dalam mukosa usus. ${ }^{22}$ Seekor cacing betina diperkirakan menghasilkan telur setiap hari antara 3000-10000 butir. ${ }^{16}$ Telur yang dibuahi dikeluarkan dari pejamu bersama tinja. Telur menjadi matang dalam waktu 3 sampai 6 minggu dalam lingkungan tanah yang lembab dan tempat yang teduh. Telur matang yang berisi larva merupakan bentuk infektif. Infeksi langsung terjadi bila pejamu menelan telur matang. Larva keluar melalui telur dan masuk ke dalam usus halus. Sesudah dewasa, cacing turun ke usus bagian distal dan masuk ke daerah kolon, terutama sekum. Masa pertumbuhan mulai dari telur yang tertelan sampai cacing dewasa betina meletakkan telur kira-kira 30-90 hari. ${ }^{7,16,22}$

Cacing trichuris terutama hidup di sekum, akan tetapi dapat juga ditemukan di kolon asendens. Pada infeksi berat, cacing trichuris tersebar di seluruh kolon dan rektum. Cacing ini memasukkan kepalanya ke dalam mukosa usus sehingga terjadi trauma yang menimbulkan iritasi dan peradangan mukosa usus. Pada tempat perlekatannya dapat terjadi perdarahan. Selain itu cacing ini menghisap darah pejamu sehingga dapat menimbulkan anemia. ${ }^{7,16,22}$

\section{Strongyloides stercoralis}

Nematoda ini terutama terdapat di daerah tropik dan subtropik sedangkan di daerah yang beriklim dingin jarang ditemukan. Daerah yang panas, kelembaban tinggi dan sanitasi yang kurang sangat menguntungkan cacing Strongyloides sehingga terjadi daur hidup yang tidak langsung. Tanah yang baik untuk pertumbuhan larva adalah tanah gembur, berpasir dan humus. ${ }^{8-10,16,22}$ Hanya cacing dewasa betina yang hidup sebagai parasit di vilus duodenum dan yeyunum dalam bentuk filiform, halus, tidak berwarna dan panjangnya kirakira $2 \mathrm{~mm}$. Parasit ini mempunyai 3 daur hidup yaitu; $7-10,16,22$

\section{Siklus langsung}

Sesudah 2 sampai 3 hari di tanah, larva rabditiform berubah menjadi larva filariform yang merupakan bentuk infektif. Bila larva filariform menembus kulit manusia akan masuk ke dalam peredaran darah vena dan melalui jantung kanan sampai ke paru. Dari paru parasit yang mulai menjadi dewasa menembus alveolus, masuk ke trakea dan laring dan dengan refleks batuk, parasit akan tertelan kemudian sampai di usus halus bagian atas dan menjadi dewasa.

\section{Siklus tidak langsung}

Di tanah larva rabditiform berubah menjadi cacing jantan dan cacing betina bentuk bebas. Sesudah pembuahan, cacing betina menghasilkan telur yang menetas menjadi larva rabditiform. Larva tersebut dalam waktu beberapa hari menjadi larva filariform yang infektif dan masuk ke dalam pejamu baru atau dapat juga mengulangi fase hidup bebas. Siklus tidak langsung ini terjadi bilamana keadaan lingkungan sekitarnya optimum misalnya di negeri-negeri tropik dengan iklim lembab.

\section{Otoinfeksi}

Larva rabditiform kadang-kadang menjadi larva filariform di usus atau di daerah sekitar anus, misalnya pada pasien yang menderita obstipasi sehingga bentuk rabditiform berubah menjadi filariform di dalam usus. Pada pasien diare menahun, bentuk rabditiform akan menjadi filariform pada tinja yang masih melekat di sekitar dubur. Bila larva filariform menembus mukosa usus atau kulit perianal, maka terjadi suatu daur perkembangan di dalam pejamu. Adanya otoinfeksi dapat menyebabkan strongiloidiasis menahun pada pasien yang hidup di daerah non endemik.

\section{E. Candida}

Penyebab tersering diare adalah Candida albicans, tetapi terdapat juga jenis lain yang juga dapat mengakibatkan kandidiasis seperti C.albicans, C.tropicalis, C.krusei, C.parapsilosis, C.stellatoidea dan C.guiliermondii. ${ }^{8,16,23-}$ ${ }^{27} \mathrm{Di}$ Amerika Serikat kandidiasis oral terjadi pada 25\% penduduk. Candida dapat menyebabkan infeksi sistemik pada $15 \%$ penduduk di dunia dan dapat menyebabkan kematian. ${ }^{23,24}$

Candida ditemukan sebagai saprofit di saluran cerna dan saluran napas. Pada manusia kandida sering ditemukan dalam mulut orang sehat, tinja, kulit dan di bawah kuku. Keadaan ini mudah menimbulkan pencemaran di lingkungan sekitarnya sehingga menjadi 
sumber infeksi. ${ }^{16}$ Seorang anak yang sehat dengan mekanisme pertahanan yang baik tidak akan mengalami infeksi jamur. ${ }^{8}$ Anak akan terinfeksi jamur bila mendapat terapi imunosupresif, regimen mielotoksik, malnutrisi kronik dan mendapatkan antimiroba secara intensif. Pasien yang dirawat di rumah sakit juga mudah mendapat infeksi kandida nosokomial. 8,16,27

\section{Manifestasi Klinis}

\section{A. Giardia lamblia}

Infeksi G. lamblia dapat bermanifestasi dalam 3 bentuk yaitu tanpa gejala, diare akut swasirna dan diare kronik dengan atau tanpa disertai malabsorbsi. ${ }^{6-10,14-19}$ Giardiasis pada anak gizi cukup akan sembuh dengan sendirinya setelah 3-6 minggu, namun terdapat sebagian kasus yang mengalami diare kronik. Ekskresi parasit dapat berlangsung selama beberapa bulan sehingga kadangkadang dapat menyebabkan reinfeksi. ${ }^{16}$

\section{B. Entamoeba histolytica}

Manifestasi klinis amebiasis dapat tanpa gejala sampai tampak sakit berat. ${ }^{6-10,13,15-18,20,21}$ Pasien amebiasis sering mengalami nyeri abdomen, diare, anoreksia dan malaise. Pada infeksi kronik, diare dapat diselingi oleh fase konstipasi. ${ }^{18}$ Diare biasanya mengandung darah dan mukus disertai tenesmus. Amebiasis intestinal dibagi menjadi 2 yaitu amebiasis kolon akut bila gejala berlangsung kurang dari 1 bulan dan amebiasis kolon menahun bila gejalanya berlangsung lebih dari 1 bulan atau bila terjadi gejala yang ringan, diikuti oleh reaktivasi gejala akut secara periodik. ${ }^{16}$

\section{Trichuris trichiura}

Kasus infeksi Trikhuris menunjukkan gejala beraneka ragam mulai dari keluhan yang ringan sampai keluhan yang berat. Gejala yang timbul dapat berupa diare yang sering diselingi dengan sindrom disentri, berat badan turun, anemia dan kadang-kadang disertai prolaps rektum. $^{7-10,16,22}$

\section{Strongyloides stercoralis}

Larva filariform dalam jumlah besar menembus kulit sehingga timbul kelainan kulit yang dinamakan creeping eruption yang sering disertai dengan rasa gatal yang hebat. Infeksi ringan Stronglioides pada umumnya terjadi tanpa diketahui pejamunya karena tidak menimbulkan gejala. Infeksi sedang dapat menyebabkan rasa sakit seperti tertusuk-tusuk di daerah epigastrium dan tidak menjalar. Dapat disertai muntah, mual, diare dan konstipasi saling bergantian. ${ }^{7-10,16,22}$

\section{E. Candida}

Kandidiasis intestinal sering ditemukan baik pada orang dewasa maupun pada bayi dengan gejala perut sering kembung dengan disertai diare. ${ }^{8,16,23-27}$ Kandida sebagai penyebab diare sampai saat ini masih menimbulkan kontroversi. Menurut Forbes kandida tidak menyebabkan diare pada anak dengan gizi baik, ${ }^{28}$ sedangkan menurut Levine kandida hanya menyebabkan diare pada keadaan tertentu saja seperti adanya defisiensi imun. ${ }^{29}$

\section{Diagnosis}

\section{A. Giardia lamblia}

Diagnosis giardiasis dapat ditegakkan dengan perjalanan penyakit. Pasien giardiasis yang bergejala akan mengeluh diare baik akut maupun kronik dan dapat diselingi oleh konstipasi. Tinja biasanya disertai dengan mukus. ${ }^{7}$ Diagnosis giardiasis dapat ditegakkan bila ditemukan trofozoit dalam tinja encer dan cairan duodenum serta bentuk kista dalam tinja padat. Morfologi G.lamblia dapat dibedakan dengan jelas dari protozoa lain dengan menggunakan sediaan basah dengan larutan iodin atau dalam sediaan yang dipulas dengan trikrom. Tehnik konsentrasi dapat meningkatkan penemuan kista. Sensitivitas metode ini berkisar $80-90 \%$ jika tinja diperiksa 3 hari berturutturut. ${ }^{16}$ Akurasi diagnostik dapat ditingkatkan dengan pemeriksaan cairan duodenum baik dengan aspirasi menggunakan selang duodenum atau menggunakan string test. ${ }^{7} 14$ Pemeriksaan serologik yang saat ini sering digunakan adalah pemeriksaan IgM anti-Giardia. Pemeriksaan IgG anti-Giardia tidak dilakukan oleh karena kadar IgG meningkat pada penduduk di daerah endemik. Penggunaan teknik lain seperti counter immuno electrophoresis, immunodiffusion dan enzymelinked immunosorbent analysis (ELISA) tidak digunakan sebagai pemeriksaan rutin sampai saat ini. ${ }^{6-10,14,16-18,19}$ 


\section{B. Entamoeba histolytica}

Diagnosis amebiasis intestinal ditegakkan dengan terdapatnya trofozoit atau kista pada sediaan tinja basah. Tinja harus diperiksa dalam 1 jam pertama dan dalam suhu kamar karena trofozoit setelah 1 jam akan lisis dan tidak dapat dikenali lagi. ${ }^{20}$ Biasanya tidak ditemukan leukosit pada pemeriksaan tinja. Tehnik konsentrasi juga dapat digunakan dengan pulasan trikrom untuk menemukan kista amuba. ${ }^{6-10,13,16-18,20,21}$ Pemberian tetrasiklin, sulfonamid, bismuth dan kaolin akan menyebabkan sulitnya identifikasi amuba. Bila tinja tidak mungkin diperiksa dalam 1 jam maka tinja dapat disimpan dalam formalin $10 \%$ untuk menemukan kista atau dalam alkohol polivinil untuk menemukan trofozoit. ${ }^{20}$ Pemeriksaan tinja dengan menggunakan 3-6 sediaan akan meningkatkan diagnosis hingga $80-90 \% .{ }^{10,20}$

Pada pemeriksaan endoskopi dapat ditemukan ulkus. Pada infeksi berat akan tampak daerah inflamasi yang luas disertai ulkus. Kolonoskopi digunakan untuk menemukan amebiasis kolon. Trofozoit juga mungkin dapat terlihat pada biopsi mukosa rektum. ${ }^{20}$ Entamoeba histolytica bersifat antigenik dan dapat menimbulkan respon imun pada pejamu. Antibodi yang terbentuk akan bertahan lama sehingga menyebabkan kesulitan untuk membedakan antara infeksi lampau atau infeksi akut, akan tetapi serologi antibodi IgG didapatkan positif pada $70-80 \%$ pasien dengan kolitis ameba. ${ }^{6-}$ $10,13,16-18,20,21$

\section{Trichuris trichiura}

Diagnosis infeksi trikuris dengan menemukan telur yang berbentuk tong di dalam tinja atau dengan pemeriksaan sediaan apus tinja. Pemeriksaan endoskopi pada kolon dan rektum kadang menunjukkan cacing dewasa menempel ke mukosa. ${ }^{7-10,16,22}$

\section{Strongyloides stercoralis}

Diagnosis pasti dengan menemukan larva rabditiform dalam tinja segar, dalam biakan atau dalam aspirasi duodenum. Biakan tinja selama sekurang-kurangnya 2x24 jam menunjukkan larva filariform dan cacing dewasa Strongyloides stercoralis yang hidup bebas. ${ }^{7-10,16,22}$ Pemeriksaan antibodi spesifik juga dapat dilakukan dengan indirect immuno fluorescence atau ELISA yang positif pada $80 \%$ kasus. ${ }^{10}$

\section{E. Candida}

Diagnosis kandidosis ditegakkan bila ditemukan kandidia dalam jaringan atau dalam bahan klinis yang diambil secara aseptik. Tinja dapat dibuat sediaan eosin, lugol atau sedaan $\mathrm{KOH}$. Jamur akan terlihat sebagai sel ragi atau hifa semu. ${ }^{16,23,24}$

\section{Tata laksana}

\section{A. Giardia lamblia}

Pengobatan giardiasis dapat menggunakan metronidazole $5-7,5 \mathrm{mg} / \mathrm{kg}$ berat badan 3 kali sehari selama 7 hari atau $30 \mathrm{mg} / \mathrm{kg}$ berat badan dosis tunggal selama 3 hari, tinidazole $30-50 \mathrm{mg} / \mathrm{kg}$ dosis tunggal, mepacrine $2 \mathrm{mg} /$ $\mathrm{kg}$ berat badan 3 kali sehari selama 7 hari, furazolidone $1,25 \mathrm{mg} / \mathrm{kg}$ berat badan, 4 kali sehari selama 7 hari. $^{8-10,14,19}$

\section{B. Entamoeba histolytica}

Terapi yang digunakan adalah metronidasol 50mg/ $\mathrm{kg}$ per hari selama 10 hari diikuti diloxanide furoate $20 \mathrm{mg} / \mathrm{kg}$ berat badan per hari selama 10 hari. ${ }^{8-10,16}$

\section{Trichuris trichiura}

Terapi yang menjadi pilihan utama saat ini adalah mebendazole dengan dosis $100 \mathrm{mg}$ per hari dua kali sehari selama 3 hari. ${ }^{7-10,16,22}$ Rerata kesembuhan trichuriasis $60-80 \%$ dengan penurunan pengeluaran telur trichuris didapatkan pada 90-99\% kasus. ${ }^{22}$

\section{Strongyloides stercoralis}

Terapi pilihan untuk pengobatan strongiloidiasis adalah tiabendasol dengan dosis $25 \mathrm{mg} / \mathrm{kg}$ berat badan selama 3 sampai 8 hari. ${ }^{7-10,16,22}$

\section{E. Candida}

Terapi yang digunakan adalah flukonasol oral $6 \mathrm{mg} /$ $\mathrm{kg}$ pada hari pertama diikuti dengan $3 \mathrm{mg} / \mathrm{kg}$ berat badan/hari untuk hari selanjutnya, itrakonasol dengan dosis $3-5 \mathrm{mg} / \mathrm{kg}$ berat badan/hari dibagi menjadi 2 atau 3 dosis, ketokonasol dengan dosis 3.3-6.6 mg/kg berat badan/hari 3 kali sehari, nistatin dengan dosis 2.500.000 U 3 kali sehari. ${ }^{23,24}$ 


\section{Daftar Pustaka}

1. Taylor DN, Connor BA, Shlim DR. Chronic diarrhea in the returned traveler. Med Clin North Am. 1999; 83:1033-52.

2. Vanderhoof JA. Diarrhea.Dalam: Wyllie R, Hyams JS, penyunting. Pediatric gastrointestinal disease, pathophysiology, diagnosis, management. Philadelphia: W.B.Saunders Company; 1993. h. 187-97.

3. Roy CC, Silverman A, Alagille D. Pediatric clinical gastroenterology, Edisi ke 4. St. Louis: Mosby; 1995. h. 21686.

4. Wang AH. Acute diarrheal diseases. Dalam: Grandell JH, McQuaid KR, Friedman SL, penyunting. Current: diagnosis \& treatment in gastroenterology. New Jersey: Prentice-Hall International, INC; 1999. h. 113-26.

5. Gracey M, Burke V. Gastrointestinal infections: mechanisms of diarrhea, pathogenesis, and clinical features. Dalam: Gracey M, Burke V, penyunting. Pediatric gastroenterology and hepatology. Edisi ke3. Boston: Blackwell Scientific Publications; 1993. h. 241-300.

6. Korman SH, Deckelbaumn RJ. Enteric Parasites. Dalam: Wyllie R, Hyams JS, penyunting. Pediatric Gastrointestinal Disease, pathophysiology, diagnosis, management. Philadelphia: W.B.Saunders Company; 1993. h. 652-69.

7. Owen RL. Parasitic diseases. Dalam: Sleisenger M, Fordtran JS, penyunting. Gastrointestinal Disease: Pathophysiology, diagnosis, management. Edisi ke 4. Philadelphia: W.B.Saunders Company; 1989. h. 1153-91.

8. Farthing MJ. Parasitic and fungal infections of the digestive tract. Dalam: Pediatric Gastrointestinal Disease: Pathophysiology, diagnosis, management. Philadelphia: B.C.Decker Inc; 1991. h. 546-56.

9. Grove DI. Parasitic intestinal infections. Dalam: Gracey M, Burke V, penyunting. Pediatric Gastroenterology and Hepatology. Edisi ke 3. Boston: Blackwell Scientific Publications; 1993. h. 318-31.

10. Farthing MJ. Parasitic infectious diarrhea. Dalam: Lebenthal E, penyunting. Textbook of Gastroenterology and Nutrition in Infancy. edisi ke 2. New York: Raven Press; 1989. h. 1135-52.

11. Fine KD, Krejs GJ, Fordtran JS. Diarrhea. Dalam: Sleisenger M, Fordtran JS, penyunting. Gastrointestinal disease: pathophysiology, diagnosis, management Edisi ke 4. Philadelphia: W.B.Saunders Company; 1989. h. 290-316.

12. Rhoads JM, Powell DW. Diarrhea. Dalam: Pediatric
Gastrointestinal Disease: Pathophysiology, diagnosis, management. Philadelphia: B.C.Decker Inc; 1991. h. 62-78.

13. Katz DE, Taylor DN. Parasitic infections of the gastrointestinal tract. Gastroenterol Clin North Am. 2001; 30:797-815.

14. Farthing MJG. Giardiasis. Dalam: Bouchier IA, Allan RN, Hodgson HJ, Keighley MR, penyunting. Gastroenterology: clinical science and practice. Edisi ke 2.London: W.B. Saunders Company LTD; 1993. h. 1363-70.

15. MacPherson DW. Intestinal parasites in returned travelers. Med Clin North Am. 1999; 83:1053-75.

16. Gandahusada S, Ilahude HH, Pribadi W, penyunting. Parasitologi kedokteran. Edisi ke 3. Jakarta: Balai Penerbit FKUI; 2002

17. Lee SD, Surawicz CM. Infectious causes of chronic diarrhea. Gastroenterol Clin North Am 2001; 30:679-92.

18. Feldman: Sleisenger \& Fordtran's Gastrointestinal and Liver Disease. Edisi ke 6. London; W.B. Saunders Company; 1998. h. 1648-79.

19. Hegar B, Sunoto. Giardiasis pada anak. Majalah Kesehatan Masyarakat Indonesia. 1996; 28:256-8

20. Zaidman I. Intestinal Amoebiasis. Dalam: Bouchier IA, Allan RN, Hodgson HJ, Keighley MR, penyunting. Gastroenterology, Clinical Science and Practice. Edisi ke 2. London: W.B. Saunders Company; 1993. h. 1451-9.

21. Yost J. Amebiasis. Pediatr Rev. 2002 Aug; 23:E293

22. Banwell JG, Variyam EP. Worm infestations. Dalam: Bouchier IA, Allan RN, Hodgson HJ, Keighley MR, penyunting. Gastroenterology, Clinical Science and Practice. Edisi ke 2. London: W.B. Saunders Company; 1993. h. 1401-18.

23. Greenberg ME. Candidiasis. Emedicine Journal. 24 Januari 2002. http://www.emedicine.com/ped/topic312.htm

24. Henderson OS. Candidiasis. Emedicine Journal. 2 Januari 2002. http://www.emedicine.com/emerg/topic76. htm

25. Moylett EH, Shearer WT. HIV: clinical manifestations. J Allergy Clin Immunol. 2002; 110:3-16.

26. Baden LR, Maguire JH. Gastrointestinal infections in the immunocompromised host. Infect Dis Clin North Am 2001; 15:639-70.

27. Wright WL, Wenzel RP. Nosocomial candida: epidemiology, transmission, and prevention. Infect Dis Clin North Am 1997; 11:411-25.

28. Forbes D. Faecal candida and diarrhoea. Arch Dis Child 2001; 84:328-31.

29. Levine J. Candida-associated diarrhea: a syndrome in search of credibility. Clin Infect Dis 1995; 21:881-6. 